\title{
A KORAI IPARI ÉPÍTÉSZET MINT A MODERN ELÖFUTÁRA
}

\author{
MARTIN PILSITZ \\ $\mathrm{PhD}$, tudományos segédmunkatárs. BME, Építésztörténeti és Müemléki Tanszék. \\ 1111 Budapest, Müegyetem rkp. 3 K II. 82. Tel.: (+36-20) 454-8261. E-mail: pilsitz.martin@gmail.com
}

\begin{abstract}
A korai ipari építészet rendkívül összetett befolyást gyakorolt a 20. század építészetére. A századfordulón az ipari építészetben sikerült legkorábban a kulcstényezők - a funkció, a szerkezet és a formavilág - összehangolása, melyből végül meggyőző építészeti kifejezési forma fejlődött ki, melyet a további fejlődés során az építészet más területein is alkalmazni kezdtek. Az ipari építészet kifejeződési formáinak kritikátlan és reflektálatlan alkalmazása az építészet más területein, például a lakásépítés területén, azonban téves fejlődéshez vezetett, melynek következményei a mai napig érezhetőek.
\end{abstract}

Kulcsszavak: történeti ipari építészet, történeti gyár, historizmus, bruitizmus, ipari mủemlék, Gubacsidülő

\section{A GYÁR - AZ IPAROSODÁS ÉPÍTÉSZETI MANIFESZTÁCIÓJA}

Az iparosodás a 19. század második felében hatalmas lendülettel fejlödött tovább, egyben mélyrehatóan és visszafordíthatatlanul alakítva át a korabeli társadalmat. ${ }^{1}$ A társadalmi átalakulás egyik fő oka, hogy a jövedelem forrását többé már nem a föld birtoklása jelentette, hanem az ipari tevékenység. Az ipari tevékenység kialakulásának fő keretfeltételei a következők: ${ }^{2}$

1. Eladható termékek gyártása

2. A termékeket felvevő piac kialakulása

3. Hatékony szállítási rendszer kiépülése a nyersanyagok és késztermékek szállítására

4. A gyártás helyszínén szabad munkaerő és tőke rendelkezésre állása

A fejlődést befolyásoló tényezők rendkívül komplex kölcsönhatásokkal jellemezhető struktúrákon keresztül kapcsolódtak egymáshoz. Ez elsőként az ipari kultúra kialakulását eredményezte, melyböl később a történeti fejlődés során kialakult az átfogó értelemben vett iparkultúra. ${ }^{3}$ A munka szociológiai fejlődéstörténete, az ipari

\footnotetext{
${ }^{1}$ Susman 1985.

${ }^{2}$ Howcroft 1998.

${ }^{3}$ Osterhammel 2009. 909.
} 
tömegtermelés és az urbanizálódás ennek az igen összetett fejlődésnek egyes elemeit alkotják, mely társadalmi fejlődés építészeti szempontból az újonnan megjelenő gyárépületekben testesült meg. Erre az összefüggésre világított rá Winkler Gábor A historizmus föbb irányzatai a XIX. század európai épitészetében címü cikkében. ${ }^{4}$

Az iparosodáshoz hasonlóan a gyár mint térbeli intézmény is olyan jelenség, mely kialakulásában nem tekinthet vissza történelmi hagyományokra. Ez további magyarázattal szolgálhat arra, hogy miért jelent olyan nehéz feladatot a történelmi gyárépületek általános építészettörténelmi besorolása. ${ }^{5}$ Ehhez járul még, hogy a gyár mint épülettípus az egyes országokban közel egyszerre jelent meg. Az azonos termékek gyártásához alkalmazott gépek a világon mindenütt ugyanúgy néztek ki, és gyártási technológiájuk is megegyezett. Ez a magyarázata annak, hogy gyártási helytől függetlenül maguk a gyártó épületek is hasonló megjelenést kaptak. ${ }^{6}$ Vannak helyi tényezők, melyek bizonyos fokig befolyásolhatták a gyárépületek építészeti kialakítását, ezek közé tartozik például a klíma vagy a helyi stilisztikai sajátosságok, melyek azonban nem változtatták meg a gyártóhely tulajdonképpeni lényegét. Ez lehet a magyarázata annak is, hogy miért olyan nehéz mind a mai napig regionális vonatkozást találni az ipari projektek építészetében.

Ebben az összefüggésben sokkal nagyobb jelentőséggel bírt a gyár-, illetve a később kialakuló ipari épület alapvető funkciója: a gyártási folyamatok háromdimenziós épületstruktúrákba vetítése. Erre az egyes iparágakban - azok specifikus gyártási eljárásai, sajátos üzemszervezete függvényében - saját épülettípusokat fejlesztettek ki, melyek mind a célszerüség mint tervezési elv mentén kerültek kialakításra, mégis térbeli kifejeződésüket tekintve gyakran ellentétes eredményhez vezettek. A gépgyártás gyártólétesítményeinél egyértelmü tendencia állapítható meg az egyszintes csarnokok javára, ahol a pillértávolság és a tetők fesztávolsága idővel folyamatosan növekedett, ami az ,általános jellegü”, vagyis specifikálatlan helyiségek kialakulásához vezetett. Az élelmiszeripar egy speciális szegmensét alkotó nagysörfözdék esetén viszont éppen ezzel ellentétes térkoncepció állapítható meg. A nagysörfőzdék egyes gyártási folyamatait befogadó helyiségek: a malátázó, az aszaló és a főzőház, illetve az additív módon egymás után elhelyezett helyiségcsoportok, mint a hủtőház, az érlelő és a raktározó létesítmények, mind magasan specifikált kialakítású helyiségek, vagyis aligha lennének alkalmasak eltérő funkciók kiszolgálására. Ezzel egyidejüleg a telephelyeken az infrastruktúra (iparvágányok, közúti csatlakozások és egyéb utak), a szociális létesítmények (kantinok, mosdók és egyéb mellékhelyiségek), valamint az energia-elóállítás létesítményei (kazán- és gépházak) integrálásával az egyes funkciók urbánus struktúrákra emlékeztető átfedései alakultak ki (1. ábra).

A 19. század közepétől csupán néhány évtized leforgása alatt olyan jelentős fejlödés zajlott le, mely a kisebb mühelyekből kiindulva a manufaktúrákon, majd gyárakon keresztül a már komoly építészeti komplexumokat alkotó hatalmas ipari üzemek

\footnotetext{
${ }^{4}$ Winkler 1975. 358.

${ }^{5}$ Pilsitz 2012.

${ }^{6}$ Vámossy 1964.
} 
kialakulásáig vezetett. Müszaki létesítményeivel, műhelyeivel, mütermeivel, irodáival és raktáraival a gyár olyan, ember által épített univerzummá vált, melynek célja, hogy mindent a gyártási folyamatnak rendeljen alá.

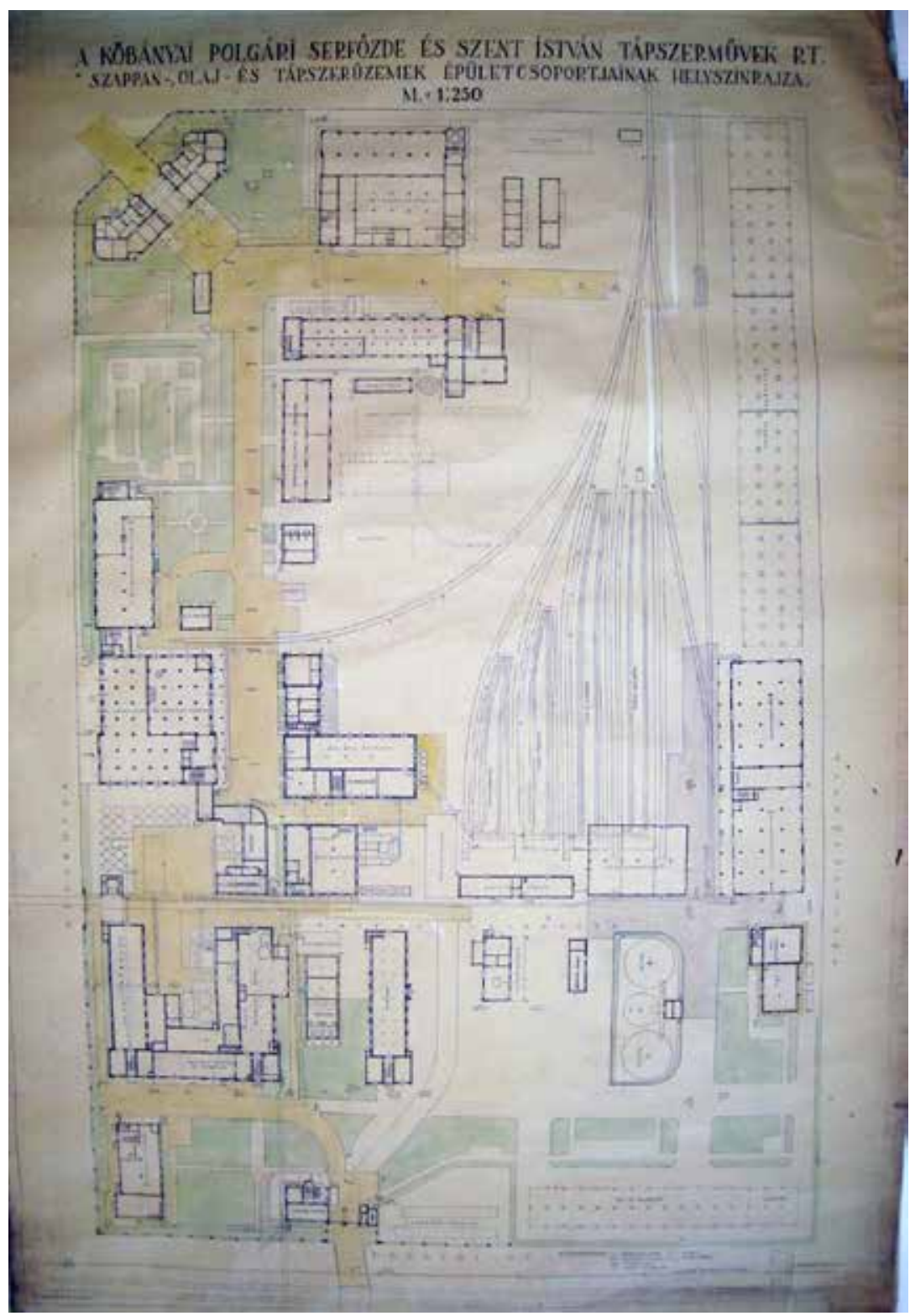

1. ábra. Polgári sörfözde. Helyszínrajz. Budapest, 1923

(Forrás: Dreher Sörgyárak Zrt. Múzeumának Archívuma) 


\section{A GYÁR IPARI ÉPÜLETTÉ VÁLÁSA}

A 20. század első évtizedében a fejlödés újabb szakaszba lépett. Ebben az időszakban a gyártó létesítmények megvalósították a gyárból az ipari épületté válás építészeti transzformációját. Ezt az evolúciós lépést a tudományosan megalapozott üzemszervezés bevezetése és a folyamatosan továbbfejlesztett gyártástechnológia kombinációja váltotta ki. ${ }^{7}$ A technológiai fejlesztések következtében ugyanis folyamatosan rövidült a gyártóberendezések csereciklusa, míg ezzel egyidejüleg a gyárépületek használati időtartama változatlan maradt. ${ }^{8}$ Ennek következtében az ipari épületeket kezdték úgy tervezni, hogy térbeli kialakításukban a lehető legmagasabb szintủ mozgásteret nyújtsák, így folyamatosan hozzáigazíthatóak legyenek a technikai és üzemszervezési fejlődéshez. ${ }^{9}$ A gépgyárak példáján keresztül erre az összefüggésre már utaltam.

\section{A FUNKCIÓ ÉS A HOMLOKZAT KÖZÖTT FESZÜLÖ KONFLIKTUS}

A rendelkezésre álló kortörténeti távolságból visszatekintve a gyárak és az ipari épületek általános építészettörténeti vetületben vizsgált fejlödéstörténetére, a 19. század utolsó harmadában uralkodó alapvető építészeti keretfeltételekre szeretnék utalni. ${ }^{10} \mathrm{Az}$ építészet alapvető problémája abban állt, hogy néhány építész igyekezete ellenére sem sikerült igazi, jövőbe mutató megoldást találni a pátosszal telt, múltba révedő historizáló stílus leváltására. ${ }^{11} \mathrm{~A}$ felhasznált építőanyagokat következetesen alapul vevő építési módokkal és az ehhez igazított formavilággal kapcsolatos elvárásokat az 1870-es évektől a Deutsche Bauzeitungban (Német Építők Újságjában) megjelenő cikksorozatban vitatták meg. ${ }^{12} \mathrm{Az}$ iparosodás következtében létrejött új épülettípusok urbánus struktúrákba illesztése jól példázza a megoldandó problémát. A hatalmas épülettömegek és térbeli dimenziók, valamint a technikai jellegü követelmények kompromisszumot tettek szükségessé az építéstechnika és az építészeti kialakítás között. Ez a megállapítás egyébként nemcsak a történelmi gyárakra volt érvényes, hanem a technikai célú épületekre általában is. Ezt az összefüggést Kubinszky Mihály ${ }^{13}$ is említi a történelmi pályaudvarok épületeinek technika- és

${ }^{7}$ Taylor 1911. 30-48, 57-60.

${ }^{8}$ Wegeleben 1924. 3-9.

${ }^{9}$ Pawlowsky 1989. 46-49.

${ }^{10}$ Pilsitz 2016.

${ }^{11}$ Ez a folyamat nem csupán néhány építész döntésén múlt, hanem az egész korszak rendkívül bonyolult társadalmi (politikai, gazdasági) problémáinak kivetülését eredményezte a művészetben, így az építészetben is. A historizmus leváltása nem csupán döntés, hanem rendkívül hosszú folyamat volt. Ezzel párhuzamos fejlődés figyelhetö meg a festészet, a szobrászat és a zene területén is.

${ }^{12} \mathrm{DB} 1870.215$.

${ }^{13}$ Kubinszky 1998. 58-60. 
kultúrtörténeti értékével kapcsolatos fejtegetéseiben. ${ }^{14} \mathrm{Ez}$ az összefüggés azért is lényeges, mert éppen ezeknek a merőben újszerü, az iparosodás következtében megjelenő épülettípusoknak az urbánus struktúrákba illesztése jeleníti meg a legélesebben azt a konfliktust, mellyel a 19. század második felének építészei szembesültek, $\mathrm{s}$ amely a nagyközönség által használt vasúti épületeken is megjelent.

Annak érdekében, hogy a pályaudvarok betölthessék funkciójukat, müszaki szempontból igényes és magas elvárásoknak megfelelni képes, ugyanakkor reprezentatív terek létrehozására alkalmas szerkezetekre volt szükség. Erre a célra nagy fesztávolságú fogadótereket fejlesztettek ki, melyek szerkezetkialakítási elveit később a gyártócsarnokok tervezésekor is felhasználták. ${ }^{15} \mathrm{~A}$ hatalmas épülettömegek és térbeli dimenziók, valamint a technikai jellegü követelmények kompromisszumot tettek szükségessé az építéstechnika és az építészeti kialakítás között. A követelményrendszer valahogy így fogalmazható meg: Modern technika? - Legyen! - Csak kifelé semmiképpen se váljon láthatóvá! Figyelemreméltó példája ennek a törekvésnek a londoni St. Pancras pályaudvar csarnoka (építész: George Gilbert Scott, az építkezés kezdete: 1864), mely 74 méteres fesztávolságával és 200 méteres hosszúságával az akkori világ legnagyobb tetőszerkezetével rendelkezett. Az elegáns acél- és üvegszerkezetről később a világ számos pályaudvarcsarnokát mintázták. ${ }^{16} \mathrm{~A}$ Barlow által tervezett szerkezetet egyébként a döntéshozók vita nélkül el is fogadták, de az előtte elterülő fogadóépületet, mely egyben a város felé mutató reprezentatív kapuként is szolgált, hatalmas nyilvános vitát követően gótikus, úgymond „méltányos” építészeti stílusban valósították meg. Az ezt követő években a racionális szempontok szerint konstruált pályaudvarcsarnokok (vagyis „kötött rendeltetésü” épületek) és gyárak túlnyomó többsége eléjük helyezett, „,eltérő építészeti stílusban tervezett” fejépítményekkel valósult meg. ${ }^{17}$

Az 1894-től folyamatosan kiépített Budapesti Első Magyar Csavargyár (EMCS) telepének üzemcsarnokai is jól mutatják, hogy a fentiekben felvázolt építészeti konfliktus több mint 25 évvel a St. Pancras pályaudvar felépülése után sem volt megoldott. ${ }^{18} \mathrm{Az}$ EMCS üzemcsarnokai egyébként a korabeli magyar szerszámgépgyártás legmodernebb gyártólétesítményei közé tartoztak. ${ }^{19} \mathrm{~A}$ shed tetős csarnokokat kompromisszummentes acél- és üvegszerkezettel készítették. Mégis, ennél a csarnoknál sem tettek kísérletet arra, hogy a modern épülettechnikát - az épület megjelenését meghatározó módon - kifelé is megjelenítsék. Ehelyett a csarnok homlokoldali bejáratát a Váci út felé masszív nyerstégla falazattal burkolták, mely két tornyával szinte középkori városkapu benyomását keltette. ${ }^{20}$ Ennek a reprezentatív épület-

\footnotetext{
${ }^{14}$ Megemlítendő ezzel kapcsolatban a Chicagói Iskola, mely föként a 19. század utolsó negyedében Chicagóban fejlesztette ki a később iroda- és üzletházak építésekor alkalmazott teherbíró acélvázszerkezetet.

${ }^{15}$ Giedion 1928 .

${ }^{16}$ Császár 1978.

${ }^{17}$ Kubinszky 1961. 109-165.

${ }^{18}$ Bencze 2006.

${ }^{19}$ Berend-Ránki 1961. 535-538.

${ }^{20}$ Panofsky 1994. 207-225.
} 
résznek múltba tekintő kialakítása és anyagválasztása számos magyarázati modellnek és elméletnek ad teret. ${ }^{21}$ Alapjában véve azonban leszögezhető, hogy a kor konzervatív homlokzati kialakítása komoly ellentmondásban áll az épületben egyébként gyártott modern termékekkel és gyártási technológiákkal. Siegfried Giedion ezt a problémát kora fogalmi lehetőségeivel így fogalmazta meg: „A 19. században a szerkezet a tudat szerepét töltötte be. Kifelé még hatásvadászóan vezeti tovább a régi pátoszt, a föld színe alatt, és a homlokzatok mögött rejtetten viszont már mai létünk alapját képezi." ${ }^{22}$

További fontos fejlődési tényezőnek tekinthető az építészet mint ágazat hierarchikus felépítése, mely a paloták, templomok, múzeumok és színházak építészetét jelentő, úgynevezett „,nagy építészetből” és az úgynevezett „egyéb építészetből” állt, melyek körébe akkoriban a lakóépületek tervezését is beleértették. Az olyan újszerü tervezési feladatok, mint az áruházak és közigazgatási épületek tervezése, valahol a két említett kategória között helyezkedtek el. Tipikus példája ennek az 1911-ben megnyílt első magyar áruház, a Párisi Nagyáruház létrejötte. Az eredetileg Petschacher Gusztáv által tervezett, háromszintes kaszinót 1910 és 1911 között Sziklay Zsigmond tervei szerint építették át áruházzá. Ennél az épületnél is modern vasbeton vázszerkezetet alkalmazott, melyet módosított formában ipari épületei tervezésekor is használt. ${ }^{23} \mathrm{~A}$ fejlődés kezdeti szakaszában a gyártóépületeket ezzel szemben nem tekintették építészt igénylő tervezési feladatnak. A gyáraknál csupán úgynevezett célépítményekröl volt szó, ami így alárendelt tervezési feladatnak számított. Ezek tervezését így gyakran a cég technikai és üzemi folyamatait jól ismerő mérnökök végezték, akik feladata a gyártólétesítmények lehető leggazdaságosabb kialakítása volt. A gyártó létesítmény és munkahely között fennálló interdependenciát, vagyis az ergonómiai, fiziológiai és szociális keretfeltételeket így a legtöbb esetben egyszerủen figyelmen kívül hagyták. Ez az összefüggés még tovább erősítette azt az általános vélekedést, hogy a gyárépületek tervezése nem számít igazán építészeti feladatnak, hiszen csupán az új technológiákat és értékes gépeket az időjárási behatásoktól védő „héj” kialakításáról van szó.

\section{ÉPÍTÉSZETI MINÖSÉGÜ IPARI ÉPÜLETEK}

Mégis talán éppen az a körülmény, hogy a gyárak tervezése az akkor általános felfogás szerint építészeti melléktevékenységnek számított, ezért nem kapcsolták más hagyományos építészeti feladatokhoz, bizonyult az innovatív kreativitás kiteljesedése kiindulási pontjának. A gyárépítészetet az építészek terra incognitának tekintették, és éppen ezért az érvényes építészeti elméletektől teljesen mentes, vagyis „szabad” területnek számított. Mivel nem támaszkodhatott múltból származó példaképekre, a három fő összetevőből: a funkcióból, a szerkezetből és a formából egé-

\footnotetext{
${ }^{21}$ Brandmann 1969. 77-79.

${ }^{22}$ Giedion 1928. 3.

${ }^{23}$ Magyar 2011. 387.
} 
szen új koncepciók alakulhattak ki. Az újonnan felfedezett építési technológiák és építőanyagok pedig még tovább erősítették ezt a fejlődési irányt. ${ }^{24}$

A számos részfolyamatra bontható, átfogó gyártási folyamat gyakran egészen komplex struktúrákat alkotott, melyeket az üzem szervezetébe és építészetileg is optimális tértervbe kellett illeszteni. Ezzel az ipari épület funkciója elsősorban már nem az időjárás viszontagságai elleni védelem funkciójában merült ki, hanem az üzemi folyamatok hálózatba szervezésében valósulhatott meg. ${ }^{25} \mathrm{Az}$ osztrák építész Bruno Bauer (1880-1938) átfogóan értelmezte az ipari épületek funkcióit, és 1916ban ezt az összetett építési feladatot találóan az alábbi mondatban foglalta össze: „, $A z$ ipari épitészet kőbe és vasba öntött üzemi diagram. ${ }^{\prime 26}$ A gyártástechnikai és üzemszervezési folyamatok hatékony szervezése és egyetlen épületben történő optimalizált elhelyezése addig ismeretlen építészeti feladatot jelentett, melynek közvetlen következtében új építészeti formák alakultak ki. Ennek során nagy segítséget jelentett, hogy a mérnökök a tulajdonképpeni probléma megoldására összpontosították figyelmüket, és a funkcióból kiindulva keresték a megoldást a lehető leghatékonyabb, vagyis leggazdaságosabb szerkezetre. Ez a megközelítés kényszerszerủen vezetett a hibás kompromisszumoktól mentes épületformákhoz. A historizmus formakialakítási problémáitól felszabadulva, az ipari építészet látszólag határtalanul szabad müvészeti teret nyitott.

Ez a rövid időtartamon belül kialakuló, egészen új formarend egyben radikális és provokatív is volt, ami később a 20. századi építészet egyik fontos kiindulópontjának is bizonyult. Ezért is nem meglepő, hogy a kor legkreatívabb építészeit is vonzani kezdte ez a tervezési feladat. Köztük Peter Behrens (az AEG turbinacsarnoka, Berlin, 1909), Walter Gropius (Fagus Müvek, Alfeld an der Leine, 1911) és Hans Poelzig (Vegyi Mủvek, Luban, 1911) számítanak a legismertebb (de közel sem egyedüli) építészek sorába, akik építészeti feladatként felvállalták a gyártóépületek tervezését, és egyéni megoldásaikkal feszegetni kezdték az építészeti kialakítás szabad mozgásterének határait. A túlhaladott elképzelésektől és hagyományoktól megszabadulva az ipari építészet így merészen jövőbemutató kísérletek terepéül szolgált. Mivel az említett építészek igen eltérő építészeti felfogással rendelkeztek, az interpretációk és megoldások szintén igen széles körben valósultak meg. Az alapelvek tekintetében azonban ettől függetlenül is egységes nézőpont alakult ki azt illetően, hogy az ipari épületek a jövőben hibás építészeti kompromisszumok nélküli külső megjelenésükben is viseljék magukon a belsejükben zajló és általuk kiszolgált funkciókat.

Ezzel a megoldási alapelvvel teljesült az a régóta kinyilvánított elvárás, miszerint az épület külső megjelenése, vagyis a homlokzata és alaprajzi kialakítása között harmóniát kell teremteni. ${ }^{27} \mathrm{~A}$ jövő gyárépületei így nem csupán növekvő számukkal és egész városképek és tájak képét átformáló hatalmas méreteikkel nyűgözték le a szemlélöket, hanem építészeti minőségükkel is. Ennek célja az épülettípus funkcio-

\footnotetext{
${ }^{24}$ Bannister 1950. 231-246.

${ }^{25}$ Georgeacopol 1998. 21.

${ }^{26}$ Bauer 1916.

${ }^{27}$ Boulée 1985. 178-180.
} 
nális jellemzőin túllépve építészeti minőségi jellemzőinek továbbfejlesztése volt. Hans Poelzig a modern gyárépítészet témakörében 1911-ben az alábbi érveket sorakoztatta fel: „A gyárépületek vagy mütárgyak terveinek esztétikai átdolgozásával megbízott vagy szakmérnökök segítségével vagy segítsége nélkül önálló tervezéssel megbízott építészek legnagyobb hozzáadott vívmányuknak tekintsék, hogy tudatosan mellőzzenek minden fajta véletlenszerü elemet és dekorációs bizarrságot. A mi korunk éppen ezekben a hatalmas gazdasági célú haszonépítményekben találja meg tökéletes kifejeződési formáját, hiszen ezek jelentik a mai építészet tulajdonképpeni monumentális feladatait. Alkalmazzuk ezért a technikailag legtökéletesebb és egyben gazdaságilag is legelönyösebb építészeti típust, és tartózkodjunk az elavult konstrukciós módszerekből eredő formanyelv építményre való rákényszerítésétől." ${ }^{28}$

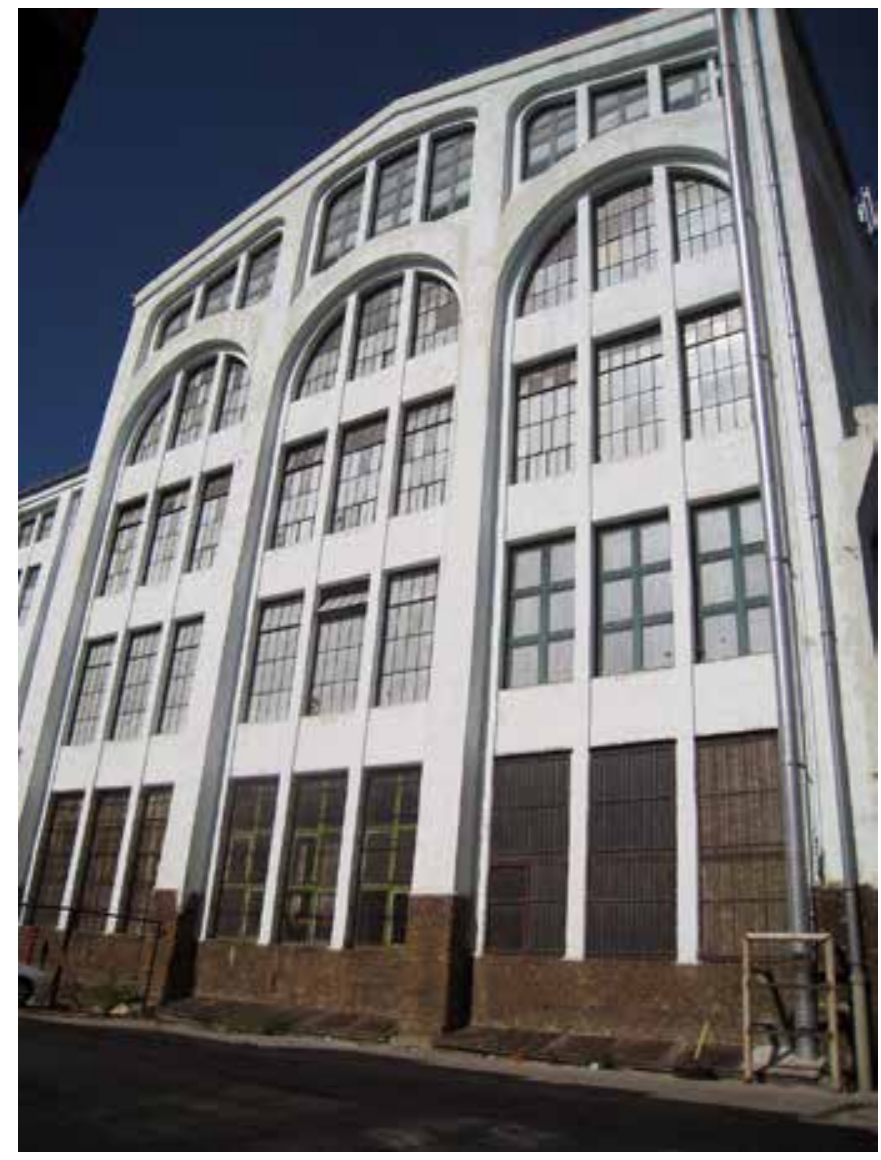

2. ábra. Vasbetonszerkezetes ipari épület. Budapest, Gubacsidűlő, 1910 (Fotó: Martin Pilsitz, 2015) 
Ez a koncepció az építészet egészének fejlődésére is hatalmas és tartós hatást gyakorolt. A retrospektív vizsgálat tehát arra is rávilágít, hogy az ipari építészet nem hogy „megfutamodott volna” a „moderntől”, hanem ennek éppen az ellenkezöje következett be, vagyis az ipari építészet a modern stílus előfutárává vált. Talán éppen ez a megközelítés világít rá a leginkább a 20. század eleji ipari építészet építészettörténeti jelentőségére (2. ábra).

\section{A FUNKCIÓ ÉS A SZERKEZET ÚJRAÉRTÉKELÉSE ÚJ FORMÁKAT IS EREDMÉNYEZ}

A budapesti Haggenmacher Sörfözde röviddel az I. világháború előtt újonnan épített malátázójának példáján keresztül jól levezethető az ipari építészet fejlődése. A Haggenmacher Sörfözde 1909-ben a müncheni Miller és Hetzel Mérnökirodát (Ingenieurbüro Miller und Hetzel) bízta meg a kőbányai malátázó tervezésével. A malátázó hozzáépített aszalóval komplex létesítményként került megtervezésre, melynek funkcionális felépítése (az árpa beszállításától egészen a sörmaláta kiszállításáig) szigorúan az egymásra épülő technológiai lépések sorrendjét követte. $\mathrm{Az}$ épület 90,23×41,02 méteres teljes méretével és négy egymás felett elhelyezett malátázó szérüjével a nagyobb üzemek közé sorolható. A malátázó szérük felett elhelyezett további négy szinten árparaktár és egy $1500 \mathrm{~m}^{3}$-es víztartály is elhelyezésre került. A gyártási kapacitás későbbi lehetséges további bővítése érdekében a kialakítás során kezdettől fogva figyelembe vették a későbbi hozzáépítés lehetőségét. A létesítményt a kor modern berendezéseivel is felszerelték, így például vákuumszivattyúkkal is ellátták. A malátázó szérüépületének alapterülete téglalap alakú volt, ami általánosságban jellemző a malátázók alapterületi kialakítására. A budafoki Haggenmacher Malátázó esetén a malátázó szérüszintje hosszirányban 4 mezőből állt, melyek fesztávolsága 7-7 méteres volt. Egy-egy mező hosszúsága közel 55 méteres volt. Ebböl malátázó szérü szintre vetítve $1540 \mathrm{~m}^{2}$-es szintterület adódik. A teherhordó szerkezeteket vasbeton pillér- és gerendaszerkezetes vázszerkezettel oldották meg. A tervből az is kiderül, hogy az épület kialakítása a malátázás mint alapfunkció messzemenő figyelembevételével történt.

A tervezési feladatnak nyilvánvalóan a funkció, a szerkezet és a forma szintézisén alapuló megoldása az épület külső formavilágán is megjelenik, amit a funkcionális esztétika fogalmával jelölhetünk. A logikusan tagolt homlokzat egyszerü geometriai alapelemekre osztható. Az uralkodó burkolóanyag a helyszínen készített és tömegtermékként kedvező áron rendelkezésre álló nyers klinkertégla. A tetőlezárás a középső épületrészben oromfal oldalra helyezett nyeregtetőkből áll. Az anyag és a forma gazdaságos alkalmazása révén ez a meggyőző épület rendkívüli tárgyilagosságot sugároz. Az épület példáján keresztül világosan levezethető a funkcionalizmusnak - az I. világháború előtti ipari építészetben - általánosan érvényes esztétikai megközelítése, mely teljesen nyilvánvalóan ekkorra már tökéletesen mentes az ideológiai vagy önkényes építészeti paradigmáktól. A funkcionális szerkezet gondo- 


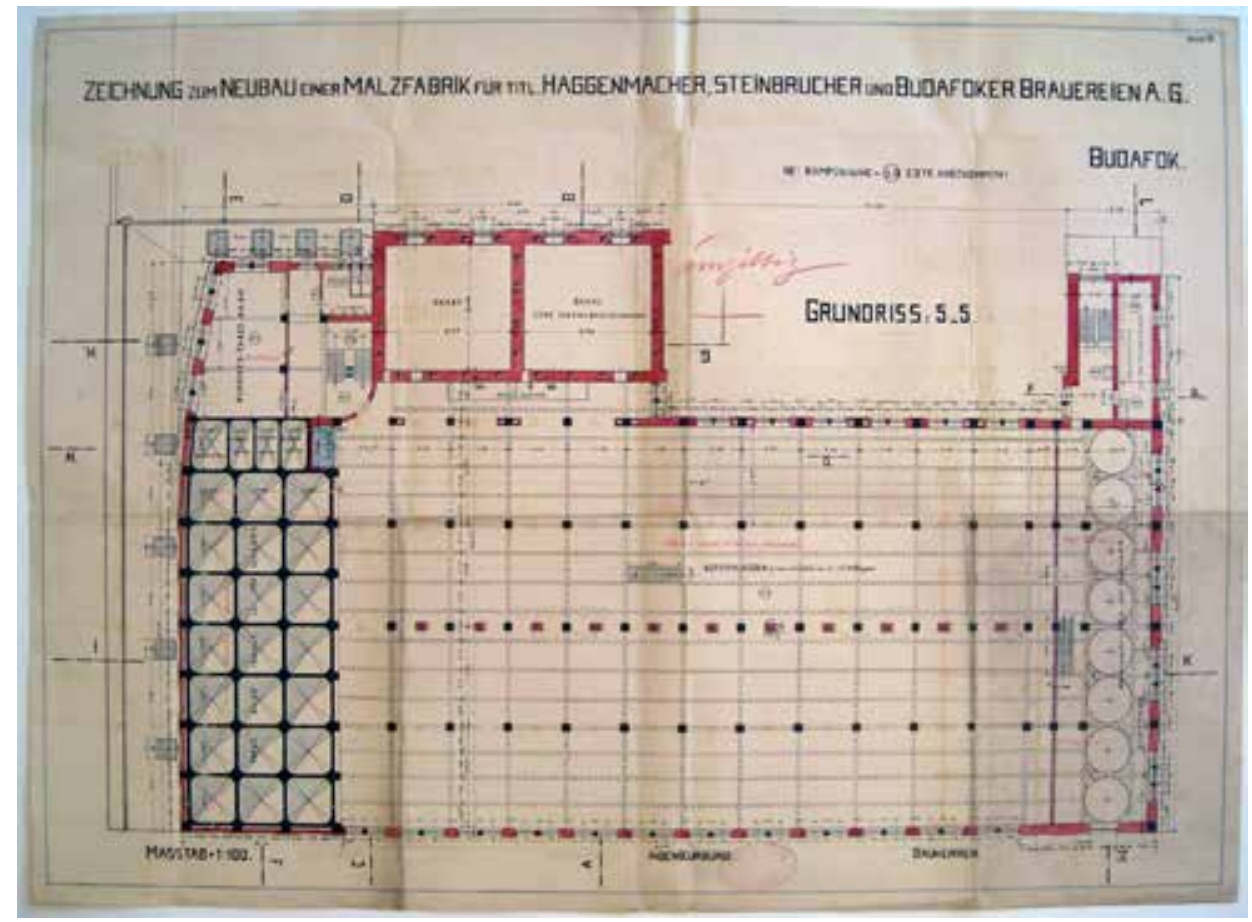

3. ábra. Haggenmacher Sörfözde. 5. emeleti alaprajz. Budapest, 1909 (Forrás: Dreher Sörgyárak Zrt. Múzeumának Archívuma)

lata a teherhordó szerkezet és a homlokzat felosztásában és az egyes területek szintmagasságában is visszatükröződik. A funkció és a szerkezet addig ismeretlen formanyelvhez vezetó át-, illetve felértékelése lesz a kiinduló pontja annak a hatásnak, melyet az ipari építészet a 20. századi építészet egészére gyakorolt (3. ábra).

\section{AZ IPARI ÉPÍTÉSZET ÉS A MODERN STÍLUS KIALAKULÁSA KÖZÖTTI KORRELÁCIÓK}

A továbbiakban vázlatosan kitérek az ipari építészet és a modern stílus alakulása közötti korrelációkra. Az avantgárd irányzathoz tartozó építészek már az I. világháború előtt megvizsgálták az ipari építészetben kifejlesztett racionális elvek általános építészetben történő alkalmazásának lehetőségeit. Az elöre gyártott építési mód egészen újszerü építészet kialakítását tette lehetővé. A gyárépítészetben alkalmazott elveket, pl. „a tér racionalizálása” és a „minél rövidebb utak” elvét így hamarosan a lakóépületek tervezésekor is alkalmazni kezdték. ${ }^{29}$ Amikor például Walter Gropius a

\footnotetext{
${ }^{29}$ Fehl 1995.
} 
Behrensnél töltött évek után 1910-ben önálló építészként kezdett tevékenykedni, az AEG igazgató tanácsához memorandumot nyújtott be a házak és berendezésük tömeggyártásában rejlő lehetőségekkel kapcsolatos elképzeléseivel. Gropius egy évvel később tervezte Alfeldben a Fagus Müveket (Fagus-Werke). A Deutscher Werkbund (Német Iparosok Szövetsége) 1914-es Kölnben rendezett kiállítására Gropius Adolf Meyerrel közösen irodaépülettel ellátott mintagyárat tervezett, ahol az újszerü elvek már éppen olyan erős hangsúlyhoz jutottak, mint a Fagus Mủvek tervezésénél. ${ }^{30}$ Ezeknek az I. világháború elött létesített gyáraknak a példáján keresztül rendkívül jól ábrázolható a szerkezet és az ipari építészetben kialakuló önálló építészet kölcsönhatása, mely az alábbi pontokban foglalható össze:

1. A célszerüség mint legfontosabb vezérlő elv alapján kialakított szerkezet teljesen átláthatóvá tétele

2. Különleges szerkezeti megoldások a növekvő alapterületủ épületek lehető legkedvezőbb természetes megvilágítása érdekében

3. A tetö- és a födémszerkezetek növekvő fesztávolságai

4. Az épületek a láthatóan kialakított szerkezeteikkel és berendezéstechnikájukkal maguk is egyre inkább gépekre kezdenek emlékeztetni. Ezzel új formáció alakul ki, melyet ,gépületnek" nevezhetünk.

5. A célszerüség és a gazdaságosság a legfontosabb vezérlő elvek. További újdonság az építőanyagok és az építményrészek tiszta egymásmellettisége.

Le Corbusier Gropiushoz hasonlóan Berlinben a Behrensnél töltött évei alatt került kapcsolatba az ipari építészettel, ami feltehetően erős befolyást gyakorolt gondolkodására és későbbi projektjeire is. 1914-ben szabadalmi oltalmat szerzett a Max Dubois mérnökkel közösen kifejlesztett „Domino” elemes építő rendszerre, mely elöre gyártott elemekből álló vasbeton vázszerkezetes épületek ipari szériagyártására vonatkozott. Ennek az ötletnek a továbbfejlesztését jelenti a későbbi, 1927-ben létrehozott új építészeti irányzatot képviselő „Citrohan” típusház is a stuttgarti Weißenhofsiedlungban. Ez a „Haus wie ein Auto” ötleten alapult, vagyis azon az elgondoláson, hogy a „házat is úgy kell megtervezni, mint egy autót”, és így keletkezett a ,lakógép” is: ${ }^{31}$ „Az életfelfogás és a lakás területén egész tudatosan elvetjük a korábbról származó konvenciókat. Új életakarás jelenik meg, mely kifejeződési lehetőséget keres a lakhatás, az állam és a müvészet területén. Enélkül a kollektív akarat nélkül nagyszerü férfiak és építészek munkája is céltalan lenne. Az ő feladatuk abban áll, hogy összefogják, és irányt adjanak a széles tömegek pulzáló erejének. Ezt az irányt nevezzük a korunk stílusának. Bennünket a korunk motorikussága érdekel, és nem stílusának filozófiája. A történelmi korok esztétikai felfogásokkal végzett

\footnotetext{
${ }^{30}$ Mielőtt 1919-ben a Bauhaus alapító tagja lett, Gropius építészként több kiemelkedő ipari épületet valósított meg. Feltételezhetô, hogy az ipari építészetben kialakult felismerései jelentős befolyást gyakoroltak a Bauhausra is, így jelentős befolyással voltak a modern építészetére is.

${ }^{31}$ Corbusier 1928.
} 
játéka bennünket már nem elégít ki. Mi saját formanyelvet és saját esztétikát alakítunk ki magunknak. És formaérzékünket a technika és az ipar letisztult célformavilágán finomítjuk. Ezek a mi szellemi gyermekeink. Ha elismerjük őket, akkor új szépségtávlatok nyílnak meg előttünk. És a szépség nemesít." ${ }^{\text {32 }}$

\section{AZ IPARI ÉPÍTÉSZET I. VILÁGHÁBORÚ UTÁNI FEJLŐDÉSE}

Az ipar I. világháború utáni fejlödését a gyárak produktivitásának további növelése, vagyis a maximálisan lehetséges darabszámok minimális gyártási költségek mellett történő előállítása jellemzi. A tömeggyártás a gazdasági siker kulcstényezöjévé vált. ${ }^{33} \mathrm{~A}$ tudományosan megalapozott és folyamatosan továbbfejlesztett üzemszervezés alkalmazásával a gyártást tovább racionalizálták. ${ }^{34}$ Az optimalizált - vagyis lehető legrövidebb és leghatékonyabb - gyártási folyamat követelményét a gyárépületek kialakítására is alkalmazták. A helyiségeket azzal a céllal racionalizálták, hogy a lehető legoptimálisabban feleljenek meg a gyártási folyamatnak. Ezzel tulajdonképpen már a szériagyártásban kialakított, optimalizált gyártási módszereket alkalmazták az ipari építészetben.

Az építőelemek előregyártásával a létesítési időtartamot is csökkenteni lehetett. Ennek következtében az ipari építészetben is bevezették a normázást, vagyis az előre gyártott és elöre szerelt elemek alkalmazását. Ezzel felfedezték az iparosított építést, melynek ráadásul elsődleges célja az ipari épületek létrehozása. Ennek során az építőelemek elöregyártása és szabványosítása elsődlegesen még technikai jellegü fejlesztést jelentett, viszont az így lerövidített építési időtartam már szervezési és gazdasági fejlődést eredményezett. A további fejlődés során az 1920-as évek végéig elsőként az USA-ban jelent meg az ipar koncentrációjának követelménye, mely végül az ipari gyártóterületek centralizációjához vezetett. Ennek következtében a túlnyomórészt vízszintesen zajló gyártási sorrendnek való építészeti megfeleltetés céljából hatalmas kiterjedésü lapos tetős épületeket létesítettek. ${ }^{35}$ Ezt az USA hatalmas kiterjedésủ és ritkán lakott államaiban aránylag könnyü volt megvalósítani, hiszen ott kedvező árú és hatalmas kiterjedésủ telkek nagy számban álltak rendelkezésre. ${ }^{36}$

Ez a trend ezután hamarosan Európában is megjelent. Ezután már az ésszerüség határainak végiggondolása nélkül, többnyire kritikátlanul ültették át az építészet más területeire - pl. a lakásépítésre - is az ipari gyártás és az ipari építészet elveit; így a legrövidebb út és az optimalizált folyamatok elvét, továbbá a hatalmas kiterjedésü lapos tetős épületekben a szériagyártásból származó előre gyártott elemek alkalma-

\footnotetext{
${ }^{32}$ Roth 1976. 25.

${ }^{33}$ Mendner 1975.

${ }^{34}$ Taylor, Frederick Winslow (1856-1915): taylorizmus, Ford, Henry (1863-1947): fordizmus

${ }^{35}$ Trambauer 1928. 192.

${ }^{36}$ Carstensen 1988. 31-39.
} 
zását. ${ }^{37}$ Ernst Maynak egy a Das Neue Frankfurt címü folyóiratban 1930-ban megjelent cikke igen érdekes részletekkel szolgál erről a jelenségről. A cikkben May részletesen elemzi a lakásépítés helyzetét Frankfurtban 1924 és 1929 között. ${ }^{38}$ May meggyőződése - miszerint az építőiparban a szabványosítás és a lakásépítés területén az előre gyártott elemekből történő építkezés régóta várt megoldás - rendkívül jól tükrözi a korabeli szakmai felfogást. ${ }^{39}$

Azonos időszakban hasonló felfogást képviselt H. Craemer (a Frankfurti Müvészeti Főiskola docense és a Frankfurti Magasépítési Hivatal tanácsosa) is: „El kell gondolkozni azon, hogy az ipari építészet - és nemcsak a vasszerkezet építés területén, hanem a még csak néhány évtizedre visszatekintő vasbeton építés területén is - már régóta megtalálta végleges megjelenési formáját. (...) Ezeknek az építményeknek a szerkezeti kialakításához túlságosan sok egzakt tudományra van szükség, mintsem hogy a divat áramlatainak legyenek kitéve (...) Az építészek alkotásai ma már túlnyomórészt célépítmények; főként a lakásépítés területén, ahol napjainkban a cél a lehető legcsekélyebb források felhasználásával a lehető legmagasabb szintü célszerüség elérése, mely tulajdonság így még nagyobb mértékben jellemzi a lakásépítést, mint az ipari építészetet." 40

A már jól ismert negatív következmények, mint például a rengeteg elöre gyártott, azonos méretủ építőelem felhasználása miatt kialakuló monotónia eredetileg nem magában az ipari építészetben gyökerezett, és nem is a felvázolt avantgárd építészettel állt összefüggésben, hanem azzal, hogy az I. világháború körüli időszakban még forradalmian újnak számító ipari építészet építészeti kifejeződési formáit később kritikátlanul vették át az építészet más területein. Ez a negatív tendencia a II. világháború után még tovább erősödött, amikor a lakásépítés területén hatalmas volumenü építkezésekre került sor, ami végül számos helyen kiábrándító lakótelepek kialakulását eredményezte. ${ }^{41}$

\section{MÜVÉSZETI REFLEXIÓK}

Az avantgárd művészeti irányok számos reflexióval reagáltak ezekre a fejleményekre. Az ipari építészet és a kubizmus, valamint a konstruktivizmus vizuális kölcsönhatása széles körben ismert. ${ }^{42}$ Több más példa mellett a Das Neue Frankfurt (Az új Frankfurt) szakfolyóirat layoutja is jól mutatja ezt a befolyást. De akadnak kevésbé ismert kölcsönhatások, pl. a zene területén is (4-5. ábra).

\footnotetext{
${ }^{37}$ Körner 2004.

${ }^{38}$ Kahnweiler 1920.

${ }^{39}$ May 1930. 21-70.

${ }^{40}$ Craemer 1929. 1-5.

${ }^{41}$ Körner 2004.

${ }^{42}$ Kahnweiler 1920.
} 


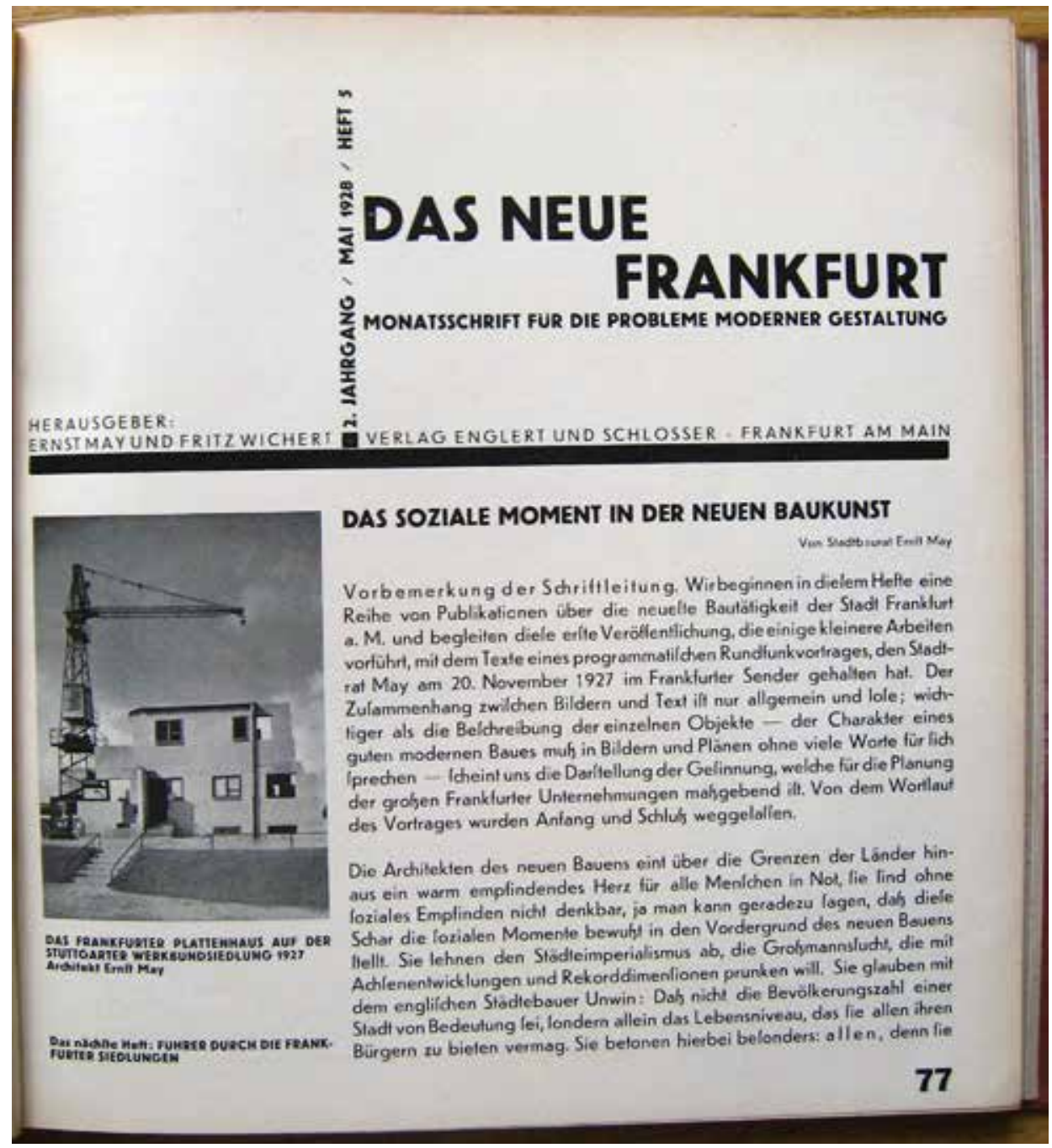

4. ábra. Das Neue Frankfurt 1928. 5. füzet. 77. oldal. layout

\section{A BRUITIZMUS}

A gépek és jármüvek mozgása folyamatos müvi zajhatást vált ki, mely az emberiség történetében ebben a formában addig ismeretlen jelenségnek számított. A bruitizmus mint zenei irányzat erre az új jelenségre reagált, és a zajok kompozíciókba 


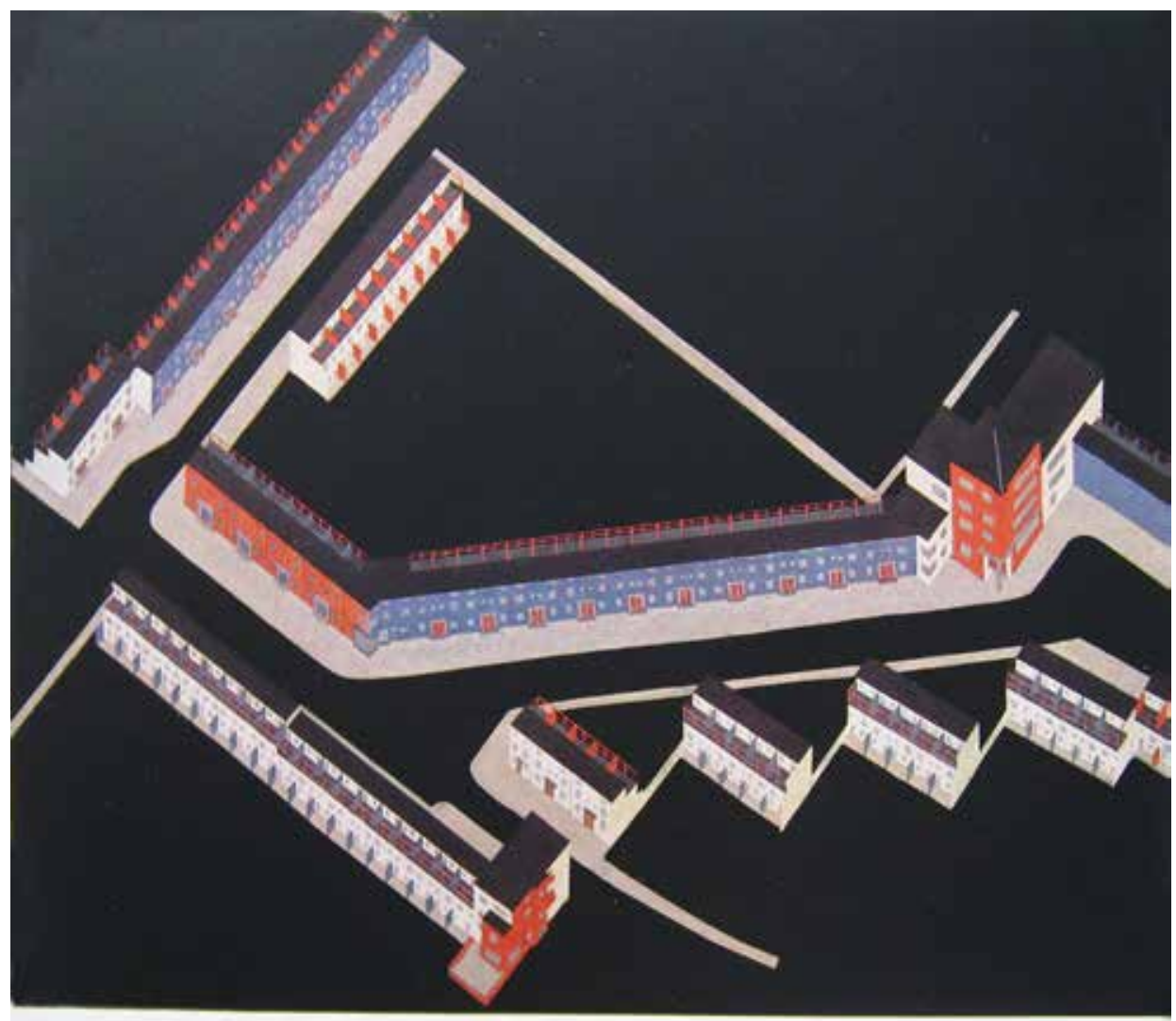

Arch.: Stadtbaurat May, Mitarb.: Baurat Kautmann Farb. Talel: Leistikow

5. ábra. Das Neue Frankfurt 1928. 112. oldal. A praunheimi lakótelep

integrálása révén igyekezett leképezni a technologizált új világot. ${ }^{43}$ 1923-ban a francia-svájci Arthur Honegger megkomponálta Pacific 231 címü új müvét. A cím a Pacific 231-es ${ }^{44}$ sorozatú mozdonyra utalt. Honegger szándéka elmondása szerint a következő volt: ,„»Pacific 231« címü szerzeményemben (...) zenei alkotás keretében (...) optikai benyomások kifejezésére törekszem (...): a még álló gép, az elindulás érdekében tett erőlködés (...), a sebesség fokozása (...)." Honegger Pacific 231 című müve tehát magát a „mozgást” mint absztrakt elvet dolgozza fel.

${ }^{43}$ A futurizmus mentén 1910 körül létrejött zenei irányzat, mely a technika világának müvészi leképezése céljából kompozícióiba zajokat integrál. http://www.enzyklo.de/lokal/42134 (Utolsó megtekintés: 2012. 12. 17.)

${ }^{44}$ A Pacific (amerikai) elnevezés a mozdony tengelyelrendezésére utal: 2-C-1, azaz két futó, 3 hajtott és egy futókerék. 
Ugyanennek a művészeti kölcsönhatásnak az ellenkező irányú megvalósulását, vagyis az érzékelés konkrét ipari folyamatban történő kifejezését tapasztaljuk a Gyárszirénák Nagy Szimfóniája keretében. A Gyárszirénák Nagy Szimfóniája címü müben 1920. augusztus 20-án az akkori Petrográdban (Szentpétervárott) egy gép a gyárszirénák ritmusában stancolt ki hangjegyeket egy $18 \mathrm{~mm}$-es acéllemezből, vagyis így a zenét kívülröl befelé transzformálta. ${ }^{45}$

\section{A MOZGÁS MEGVÁLTOZTATJA AZ ÉRZÉKELÉST}

Az olasz-svájci futurista Alberto Sartoris ugyan nem tartozik az építészetelmélet azon személyiségei közé, akik hatást gyakoroltak volna a vizsgált korszak fejlödésére, mégis a mozgás jelenségének építészetbe illesztésével kapcsolatos koncepciója alapvető jelentőségü. ${ }^{46} \mathrm{Az}$ iparosodás korában a gépek általi mozgás fizikai jelensége alapvetően megváltoztatta az esztétikai térélményt. Vegyük például egy vonat pályaudvari csarnokba történő behajtását, melynek során az utasok perspektivikus érzékelése folyamatosan változik. ${ }^{47}$

\section{ÖSSZEFOGLALÁS}

Az 1850-es évektől a gyárépítészetben folyamatos fejlődés indult be, mely a 20 . század kezdetén ipari építészetté alakult át, és majd valamikor a jövőben a káros anyag kibocsátás nélküli gyárban fogja megtalálni következő állomását. ${ }^{48}$ Kezdeti fejlődési szakaszában az ipari építészet a funkció és a szerkezet tényezőinek újraértékelésével túllépett a historizáló megközelítésen, ezzel új formanyelvet teremtett, mely olyan meggyőző volt, hogy az avantgárd építészei is befogadták, és így a modern stílusirányzat előfutárává válhatott. Az ipari építészet építészeti kifejeződési formáinak reflektálatlan és kritikátlan átültetése az építészet más területeire - például a lakásépítés területére - azonban hibás fejlődési tendenciákat eredményezett, melynek negatív következményei a mai napig megoldatlanok. ${ }^{49}$

\footnotetext{
${ }^{45} \mathrm{http}: / /$ www.museumderunterhoertendinge/dinge_1999/noten/noten.htm (Utolsó megtekintés: 2012. 12. 15.)

${ }^{46}$ Sartoris 1932.

${ }^{47}$ A mozgás mint esztétikai érzékelési jelenség már a gótika korában is számos elmélkedés témája volt, majd a 19. században Viollet-le-Duc foglalkozik vele ismét. Ez a vonulat ezután egészen Calatrava spanyol építész közlekedési építményeiig nyomon követhető.

${ }^{48}$ www.fabrikderzukunft.at/fdz_pdf/broschuere_projektbeispiele.pdf (Utolsó megtekintés: 2012. 08. 30.)

${ }^{49}$ Ferkai 2005.
} 


\section{FELHASZNÁLT IRODALOM}

Bannister 1950

Bauer 1916

Bencze 2006

Berend-Ránki 1961

Boullée 1985

Brandmann 1969

Carstensen 1988

Corbusier1928

Craemer 1929

Császár 1978

DB 1870

Fehl 1995

Ferkai 2005

Georgeacopol 1998

Giedion 1928

Howcroft 1998

Kahnweiler 1920

Körner 2004

Kubinszky 1961

Kubinszky 1998

Magyar 2011

May 1930

Mendner 1975
Turpin Bannister: The first iron-framed buildings. Architectural Review 108 (April 1950) 231-246.

Bruno Bauer: Das Problem des Industriebaus. ZÖIAV - Zeitschrift des Österreichischen Ingenieur- und Architektenvereins 68 (1916).

Bencze Géza: Váci út, a magyar gépipar föutcája. Országos Pedagógiai Könyvtár és Múzeum, Budapest 2006.

Berend Iván - Ránki György: A Budapest környéki ipari övezet kialakulásának és fejlödésének kérdéséhez. In: Tanulmányok Budapest Múltjából XIV. Akadémiai Kiadó, Budapest 1961.

E.-L. Boullée: Essai sur l'art. In: Geschichte der Architekturtheorie 1985. Günter Brandmann: Bemerkungen zu einer Ikonologie des Materials. Städel-Jahrbuch 2 (1969) 77-79.

Vernon Carstensen: Patterns of the American Land. Journal of Federalism 18 (1988) 4. Fall.

Le Corbusier: Wie wohnt man in meinen Stuttgarter Häusern? Das Neue Frankfurt 3 (1929), 2 (1928) 13-15.

H. Craemer: Was können wir Ingenieure zur Genesung der Baukunst beitragen? Das Neue Frankfurt 3 (1929) 1-5.

Császár László: Korai vas és vasbeton épitészetünk. Müszaki Könyvkiadó, Budapest 1978.

Zur Ästhetik des Backsteinbaus. Deutsche Bauzeitung 4 (1870) 27.

Gerhard Fehl: Zukunft aus Amerika. Fordismus in der Zwischenkriegszeit: Siedlung, Stadt, Raum. Regina Bittner (Stiftung Bauhaus Dessau. RWTH Aachen). Berlin 1995.

Ferkai András: Lakótelepek. Budapest Fővárosi Önkormányzat Főpolgármesteri Hivatal, Budapest 2005.

Ute Georgeacopol-Winischhofer: Vom Arbeitshaus zur Großindustrie. Österreichischer Kunst und Kulturverlag, Wien 1998. 21-22.

Siegfried Giedion: Bauen in Frankreich - Bauen in Eisen, Bauen in Eisenbeton. Klinkhardt und Biermann Verlag, Leipzig 1928. 3.

Tom Howcroft: Erhaltung und Umnutzung von Industriebauten des 19. Jahrhunderts in Nordwestengland. In: Dokumentation der Jahrestagung 1993 in Manchester und Liverpool. Arbeitskreis Theorie und Lehre der Denkmalpflege e.V. Bamberg 1998.

Daniel-Henry Kahnweiler: Der Weg zum Kubismus. Verlag Gerd Hatje, Stuttgart 1920.

Körner Zsuzsanna: A telepszerü lakásépités története Magyarországon 1850-1945. Urbanisztikai füzetek 3. Terc Kft., Budapest 2004.

Kubinszky Mihály: A vasutak épitészete Európában. Épités- és Közlekedéstudományi Közlemények 5 (1961) 1-2. 109-165.

Kubinszky Mihály: A pályaudvar mint műemlék. Új Magyar Épitőmüvészet (1998) 3. 58-60.

Magyar Zoltán: Kísérlet a beton történetének megfogalmazásához. Épités - Épitészettudomány. 39 (2011) 3-4. 353-410.

Ernst May: Fünf Jahre Wohnungsbautätigkeit in Frankfurt. Das Neue Frankfurt 4 (1930) 21-70.

Jürgen Mendner: Technologische Entwicklung und Arbeitsprozess. Frankfurt am Main, 1975. 
Osterhammel 2009

Panofsky 1994

Pawlowsky 1989

Pilsitz 2012

Pilsitz 2016

Poelzig 1911

Roth 1976

Sartoris 1932

Susman 1985

Taylor 1911

Trambauer 1928

Vámossy 1964

Wegeleben 1924

Winkler 1975
Jürgen Osterhammel: Die Verwandlung der Welt - Eine Geschichte des 19. Jahrhunderts. C.H. Beck Verlag, München 2009. 909.

Erwin Panofsky: Ikonographie und Ikonologie. In: E. Kaemmerling (Hrsg.): Bildende Kunst als Zeichensystem. Ikonographie und Ikonologie. Band 1. Köln 1994. 207-225.

Peter Pawlowsky: Moderne Zeiten - Zweiter Teil. Psychologie Heute (1989) 12. 46-49.

Martin Pilsitz: Mủemlék az ipari építészetben. Épités - Épitészettudomány 40 (2012) 1-2. 97-112.

Martin Pilsitz: Felvetések a budapesti történeti gyárépületek homlokzati kialakításával kapcsolatban. Épités - Épitészettudomány 44 (2016) 1-2. 25-43.

Hans Poelzig: Der neuzeitliche Fabrikbau. Der Industriebau 2 (1911) 100-106.

Paul W. Roth: Industriespionage im Zeitalter der Industriellen Revolution. Blätter für Technikgeschichte (1976) 38. 25.

Alberto Sartoris: Gli elementi dell'architettura razionale. Milano 1932.

Warren Susman: Culture as History: The Transformation of American Society in the twentieth Century. New York 1985.

Frederick Winslow Taylor: The Principles of Scientific Management. Harper \& Brothers, New York 1911. 30-48, 57-60.

Fritz Trambauer: Das flache Dach im Industriebau. Das Neue Frankfurt 3 (1928) Sondernummer 7. 192.

Vámossy Ferenc: Az ipari építészet fejlődése. Magyar Épitómüvészet 2 (1964) 61-63.

F. Wegeleben: Wege der Rationalisierung im Maschinenbau. Berlin 1924. 3-9.

Winkler Gábor: A historizmus főbb irányzatai a XIX. század európai építészetében. Épités- Épitészettudomány 3 (1975) 3-4. 357-367.

\section{INTERNETES FORRÁSOK}

www.fabrikderzukunft.at/fdz_pdf/broschuere_projektbeispiele.pdf (Utolsó megtekintés: 2012. 08. 30.) www.enzyklo.de/lokal/42134 (Utolsó megtekintés: 2012. 12. 17.)

www.museumderunterhoertendinge/dinge_1999/noten/noten.htm (Utolsó megtekintés: 2012. 12. 15.)

\section{HISTORIC INDUSTRIAL ARCHITECTURE PAVING THE WAY FOR MODERNISM}

\section{Summary}

Since 1850 factory architecture has been evolving continuously, making its transition to industrial architecture during the early 20th century to presumably culminate in the prospective zero-emission factory. By re-evaluating the concepts of function and design industrial architecture moved beyond Historicism, creating a new design language so powerful and convincing that it was adopted by avant-garde architects thus paving the way for Modernism. The tendency to use design forms related to 
industrial architecture and inconsiderately and indiscriminately transfer them to other architectural sectors, such as housing, however, gave rise to undesirable developments whose impact we still have to face today.

Keywords: industrial architecture, historical factory, Historicism, Bruitism, Gubacsi-Meadow, protected historic monument

\title{
DIE HISTORISCHE INDUSTRIEARCHITEKTUR ALS WEGBEREITER DER MODERNE
}

\begin{abstract}
Zusammenfassung
Seit 1850 ist im Fabrikbau eine kontinuierliche Entwicklung festzustellen, die Anfang des 20. Jahrhunderts in den Industriebau übergegangen ist und in Zukunft in der emissionsfreien Fabrik ihren vorläufigen Abschluss finden wird. Der Industriebau hat zu Beginn seiner Entwicklung durch die Neubewertung der Faktoren Funktion und Konstruktion den Historismus überwunden und eine neue Formensprache hervorgebracht, die so überzeugend war, dass sie von Architekten der Avantgarde aufgenommen und zum Wegbereiter der Moderne wurde. Die unreflektierte und kritiklose Übernahme architektonischer Erscheinungsformen des Industriebaus auf andere Baubereiche, wie dem Wohnungsbau führten jedoch zu Fehlentwicklungen, mit deren Folgen wir heute zu kämpfen haben.
\end{abstract}

Schlüsselwörter: Industriearchitektur, historische Fabrik, Historismus, Bruitismus, Industriedenkmal, Gubacsi-Gelände 